\title{
An Empirical Analysis of Income Expectations and Interstate Migration
}

\author{
Richard J. Cebula and Richard K. Vedder*
}

Income expectations have been examined at considerable length as a result of their central role in the "permanent income" hypothesis formulated initially by Friedman [10] and in the "life cycle" hypothesis formulated by Ando and Modigliani [1]. ${ }^{1}$ Income expectations have also been investigated in terms of their impact on a number of other issues, including investment in human capital, ${ }^{2}$ the efficacy of economic stabilization policies, and migration. ${ }^{3}$

This paper seeks to extend the latter body of literature by investigating how and to what extent certain income expectations proxies may influence human migration decisions in the United States.

Section I provides the basic theoretical framework (model) of the paper, while Section II provides an empirical framework for the analysis of the relationship between labor migration and expected income changes. Section III uses multiple linear regression analysis to evaluate the framework in Section II. An alternative model is developed and tested in Section IV. Concluding remarks are offered in the final section of the paper.

\section{Investment in Migration}

The basic framework of the paper is one in which the individual chooses to migrate from one area to another if over time there are positive net benefits from such migration. In particular, we maintain that an individual residing in area $\underline{i}$ will choose to migrate to area $\underline{j}$ only if the discounted present value of the $\bar{n} e t$ benefits associated with the migration is positive. Thus, assuming that all of the various benefits and costs that can be associated with migration can be expressed in pecuniary terms, ${ }^{4}$ we argue that

$$
\begin{aligned}
& \text { (1) Mij }>0 \text { only if } \\
& \frac{\mathrm{B}_{1}-\mathrm{C}_{1}}{(1+\mathrm{r})}+\frac{\mathrm{B}_{2}-\mathrm{C}_{2}}{(\mathrm{l}+\mathrm{r})^{2}}+\ldots+\frac{\mathrm{B}_{\mathrm{n}}-\mathrm{C}_{\mathrm{n}}}{(1+\mathrm{r})^{\mathrm{n}}}>0,
\end{aligned}
$$

where $\mathrm{B}_{\mathrm{e}}, \mathrm{e}=1, \ldots, \mathrm{n}$, represents the value of all the benefits associated with migration from area $\underline{i}$ to area $\underline{j}$ for year $\underline{e}, \mathrm{C}_{e}, \underline{e}=1, \ldots, n$, represents the value of all the costs associated with migration from area $i$ to area $j$ for year $\underline{e}, r$ is the appropriate rate of discount for the individual, and Mij denotes migration from area $\underline{\mathrm{i}}$ to area $\underline{\mathrm{j}}$.

*Emory University and Ohio University, respectively. 
Now, the analysis of the net benefits of migration (which clearly need not be positive) involves appraisal of all the benefits and of all the costs associated with migration. There may, of course, be many different sources of benefits and of costs from migration which may accrue over a given time period (year). The total gross value of the benefits accruing from migration in the eth year, $\mathrm{B}_{\mathrm{e}}$, may thus be represented as

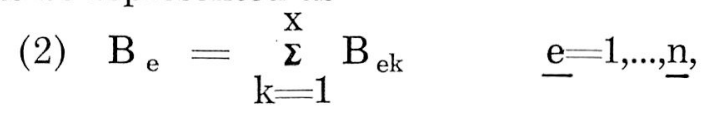

where $\mathrm{B}_{\mathrm{ek}}, \mathrm{k}=1, \ldots, \mathrm{x}$, is the value of the $\mathrm{kth}$ form of benefit accruing from migration in year e. Similarly, the total gross value of the costs accruing in the eth year, $\mathrm{C}_{\underline{e}}$, may be represented as

$$
\text { (3) } \overline{\mathrm{C}}_{\mathrm{e}}={ }_{\mathrm{m}=1}^{\mathrm{Z}} \mathrm{C}_{\mathrm{em}} \quad \underline{\mathrm{e}}=1, \ldots, \mathrm{n}
$$

where $\mathrm{C}_{\mathrm{em}}, \underline{\mathrm{m}}=1, \ldots, \underline{\mathrm{z}}$, is the value of the $\underline{\mathrm{m}} \mathrm{th}$ form of cost experienced (accruing) in year $\underline{\text { e. }}$

It follows from (1), (2), and (3) that migration from area $\underline{\mathrm{i}}$ to area $\underline{\mathrm{j}}$, $\underline{\mathrm{Mij}}$, is a function of $\mathrm{B}_{\mathrm{ek}}$ and $\mathrm{C}_{\underline{\mathrm{em}}}$ such that

$$
\operatorname{Mij}=\operatorname{Mij}\left(B_{e k}, C_{e m}\right) \quad \begin{aligned}
& k=1, \ldots, \underline{x} \\
& \\
& m=1, \ldots, \underline{\underline{z}} \\
& \\
& e=1, \ldots, \underline{n}
\end{aligned}
$$

and

$$
\begin{array}{ll}
\frac{\partial \mathrm{Mij}}{\partial \mathrm{B}_{\mathrm{ek}}}>0 & \text { for all } \frac{\mathrm{k}}{\mathrm{e}} \\
\frac{\partial \mathrm{Mij}}{\partial \mathrm{C}_{\mathrm{em}}}<0 & \text { for all all } \underline{\mathrm{m}} \\
& \text { for all } \underline{\mathrm{e}}
\end{array}
$$

The primary emphasis of this paper is on the impact of income expectations on migration. Accordingly, we note that the income increase expected from migration in year $\mathrm{e}$ can be represented as one of the $\mathrm{x}$ benefits accruing from migration in year $\mathrm{e}, \mathrm{e}=1, \ldots, \mathrm{n}$. More generally, the income increase expected from migration in any time period represents one of the benefits from migration accruing in that time period. It follows then from (4) that

$$
\text { (5) } \frac{\partial \mathrm{Mij}}{\partial \text { Y̌aij }}>0 \text { for all } \underline{a} \text {, }
$$

where Yaij is the expected increase in income in period a from migration from area i to area j. 
In this paper, it is assumed initially that the income increase expected in an area over a period of time depends upon the rate of the area's income growth over the previous time period. Thus, the income change expected for the ten year period 1960-1970 would depend in part upon the income growth rate over the prior ten year period: 1950-1960. The rate of income growth in area $\underline{\mathrm{i}}$ is measured hereby the percentage

$$
\frac{{ }^{{ }_{1} 1960}-{ }^{Y_{1950}}}{{ }^{Y_{1960}}}=\Delta \mathrm{Yi}
$$

Thus, $\Delta \mathrm{Yi}$, as defined here, is treated as a proxy for expected future income changes for the following ten-year time period (1960-1970) in area $\underline{i}$.

Given the argument presented above, the next section of this paper addresses empirically the following question: Has migration in the United States over various time periods in fact been responsive to expected income changes, and if so, to what extent?

\section{An Empirical Framework}

To investigate empirically the impact of income expectations on migration, we first postulate the following migration model:

(7) $\mathrm{Mi}=\mathrm{Mi}\left(\mathrm{Yi}, \mathrm{Yi}^{*}, \mathrm{Ci}, \mathrm{Pi}\right)$,

where $\underline{\mathrm{Mi}}$ is net migration into area $\underline{\mathrm{i}}, \underline{\mathrm{Yi}}$ is current per capita personal income in area $\mathrm{i}, \overline{\mathrm{Y}}_{\mathrm{i}}^{*}$ is expected future income increases associated with migration to area $\mathrm{i}, \mathrm{Ci}$ is the number of days per year when the temperature in area $\mathrm{i}$ fell to $32^{\circ}$ $\overline{\mathrm{F}}$ arenheit or below, and $\underline{\mathrm{Pi}}$ is the population per square mile in area $\underline{\mathrm{i}}$.

We impose the following restrictions on the partial derivatives in (6):

$$
\begin{array}{ll}
\frac{\partial \mathrm{Mi}}{\partial \mathrm{Yi}}, & \frac{\partial \mathrm{Mi}}{\partial \mathrm{Yi}^{*}}>0, \\
\frac{\partial \mathrm{Mi}}{\partial \mathrm{Ci}}, & \frac{\partial \mathrm{Mi}}{\partial \mathrm{Pi}}<0
\end{array}
$$

The sign of $\partial \mathrm{Mi} / \partial \mathrm{Yi}$ follows from orthodox theory, while the sign of $\partial \mathrm{Mi} / \partial \mathrm{Yi}$ follows from (5) and (6) above and the discussion thereof. Namely, it is argued that, on average, migrants are attracted to those areas which exhibit the greatest income growth since in such areas incomes may well be expected over time to rise the most rapidly. The sign of $\partial \mathrm{Mi} / \partial \mathrm{Ci}$ follows from the fact that, on average, people prefer warmer or more moderate climates to colder climates. Finally, the sign of $\partial \mathrm{Mi} / \partial \mathrm{Pi}$ follows from the notion that as population density rises, so do congestion, risk of loss from crime, loss of privacy, pollution, etc.

In the empirical testing in Section III below, $\Delta \mathrm{Yi}$ from equation (6) is used as the proxy for $\underline{Y}$ i. Accordingly, we may rewrite migration equation (7) as 
(9)

$$
\begin{aligned}
\mathrm{Mi}= & \mathrm{Mi}(\mathrm{Yi}, \Delta \mathrm{Yi}, \mathrm{Ci}, \mathrm{Pi}), \\
& \partial \mathrm{Mi} / \partial \Delta \mathrm{Yi}>0 .
\end{aligned}
$$

The specific regression equation to be estimated is

(10) $\mathrm{Mi}=\mathrm{a}+\mathrm{bYi}+\mathrm{c} \Delta \mathrm{Yi}+\mathrm{dCi}+\mathrm{ePi}+\mathrm{u}$,

where $\underline{a}$ is a constant and $\underline{\mathrm{u}}$ is a random error term.

\section{Empirical Results}

We use Stanley Lebergott's estimates of net migration by states, except for the 1960-70 decade, where we use Census estimates (Lebergott [16, 846-847] and Department of Commerce $[6,15]$. The net migration estimates are for internal migration only (excluding immigrants) except for the 1960's, where immigrants are included in the data. The state personal income per capita data used in our analysis are taken from two sources. We use Richard Easterlin's estimate for 1880, 1900, and 1920 (Easterlin [8,753]). For 1930, 1940, 1950, 1960, and 1970, we use Department of Commerce estimates (Department of Commerce $[7,13]$; Department of Commerce $[6,314]) .^{5}$ The population density and climate data were also obtained from Department of Commerce sources (Easterlin $[8,349]$; Department of Commerce $[6,12,164])$. To get state estimates of the number of days per year below freezing, we took the arithmetic mean of the average number of cold days for all the weather stations in each state for which data were reported in the 1971 Statistical Abstract of the United States $[6,173]$.

As shown in Table 1, the results overall are gratifying. In six of nine instances, the model explains a majority of the variation in net migration between the states. In 33 of 36 cases, the observed relationship between net migration and the independent variables is in the postulated direction; in 27 instances, the results are significant at the five percent level using a one-tailed test.

Most important, the empirical results support our hypothesis concerning the relationship between both $\mathrm{Mi}$ and $\mathrm{Yi}$ and $\mathrm{Mi}$ and $\Delta \mathrm{Yi}$. Our variable measuring $\mathrm{Yi}$ has the expected positive sign and is statistically significant at the five percent level in every instance. Our proxy for expected income, $\Delta \mathrm{Yi}$, has the expected positive sign in seven of nine instances. In addition, it is statistically significant in five cases at the five percent level, and in six cases at the ten percent level. Of the three cases where the results were not significantly positive at the 10 percent level, two were for early decades (1890-1900, 1900-1910) where the probability of error in the measurement of $\Delta \mathrm{Yi}$ is fairly substantial. The only other case where $\Delta$ Yi did not work as expected was the decade of the 1940's - a period encompassing the massive disruptions associated with World War II. ${ }^{6}$ This general strength of $\Delta \mathrm{Yi}$ is compatible with a number of recent studies, including Pack [20] and Cebula and Vedder [5].

The empirical results also support the hypothesis that migrants, ceteris paribus, prefer to avoid cold climates $^{\tau}$, and prefer less congested (densely populated) 
TABLE I

Net Migration Regression Results, 1880-1970+

\begin{tabular}{|c|c|c|c|c|c|c|}
\hline Period & $\mathrm{Yi}$ & $\mathrm{Yi}$ & $\mathrm{Ci}$ & $\Delta \overline{P i}^{\#}$ & $\mathbf{R}^{2}$ & F Ratio \\
\hline $1880-1890$ & $\begin{array}{l}0.27908 * * \\
(0.08975)\end{array}$ & $\begin{array}{c}0.48092^{*} \\
(0.25676)\end{array}$ & $\begin{array}{c}-0.01847 \\
(0.09362)\end{array}$ & $\begin{array}{c}-0.09906^{*} \\
(0.07359)\end{array}$ & .2607 & $3.614 * *$ \\
\hline $1890-1900$ & $\begin{array}{l}0.14557 * * \\
(0.03498)\end{array}$ & $\begin{array}{c}0.08347 \\
(0.10014)\end{array}$ & $\begin{array}{r}-0.04975 \\
(0.03649)\end{array}$ & $\begin{array}{c}0.01519 \\
(0.02328)\end{array}$ & .3520 & $5.569 * *$ \\
\hline $1900-1910$ & $\begin{array}{l}0.17137 * * \\
(0.03851)\end{array}$ & $\begin{array}{c}-0.01340 \\
(0.05360)\end{array}$ & $\begin{array}{c}-0.07032^{* *} \\
(0.04156)\end{array}$ & $\begin{array}{c}-0.07047 * * \\
(0.02391)\end{array}$ & .5822 & $14.633^{* *}$ \\
\hline $1910-1920$ & $\begin{array}{l}0.12272^{* *} \\
(0.02018)\end{array}$ & $\begin{array}{l}0.04709 * * \\
(0.02721)\end{array}$ & $\begin{array}{c}-0.08941^{* *} \\
(0.02202)\end{array}$ & $\begin{array}{r}-0.01508 * \\
(0.01012)\end{array}$ & .5950 & $15.795 * *$ \\
\hline $1920-1930$ & $\begin{array}{l}0.04520 * * \\
(0.00632)\end{array}$ & $\begin{array}{c}0.23318 * * \\
(0.10560)\end{array}$ & $\begin{array}{c}-0.12972 * * \\
(0.02093)\end{array}$ & $\begin{array}{c}-0.02059 * * \\
(0.00949)\end{array}$ & .6680 & $21.627 * *$ \\
\hline $1930-1940$ & $\begin{array}{l}0.03875 * * \\
(0.00575)\end{array}$ & $\begin{array}{c}0.22009 * * \\
(0.08625)\end{array}$ & $\begin{array}{c}-0.06620^{* * *} \\
(0.01653)\end{array}$ & $\begin{array}{c}-0.02166 * * \\
(0.00655)\end{array}$ & .5500 & $\begin{array}{r}13.139 * * \\
* *\end{array}$ \\
\hline $1940-1950$ & $\begin{array}{l}0.05726 * * \\
(0.01145)\end{array}$ & $\begin{array}{r}-0.05173 \\
(0.04955)\end{array}$ & $\begin{array}{c}-0.11441^{* *} \\
(0.02171)\end{array}$ & $\begin{array}{c}-0.03479 * * \\
(0.00847)\end{array}$ & .6830 & $23.165 * *$ \\
\hline $1950-1960$ & $\begin{array}{l}0.04487 * * \\
(0.00643)\end{array}$ & $\begin{array}{l}0.53200 * * \\
(0.20093)\end{array}$ & $\begin{array}{c}-0.10675^{* *} \\
(0.02885)\end{array}$ & $\begin{array}{c}-0.02144 * * \\
(0.00903)\end{array}$ & .5792 & $14.799 * *$ \\
\hline $1960-1970$ & $\begin{array}{l}0.02991^{* *} \\
(0.00614)\end{array}$ & $\begin{array}{l}0.34256 * * \\
(0.17096)\end{array}$ & $\begin{array}{c}-0.05349 * * \\
(0.02883)\end{array}$ & $\begin{array}{c}-0.01873^{* *} * \\
(0.00834)\end{array}$ & .4470 & $8.690 * *$ \\
\hline
\end{tabular}

+ Numbers in parentheses are standard errors of estimates.

\# $\Delta \mathrm{Yi}$ is for the same period as the migration, except before 1920. See text.

*Significánt at the ten percent level.

**Significant at the five percent level. 
areas. In the case of our measure of $\mathrm{Ci}$, the results are statistically significant at the five percent level in seven instances; with respect to $\mathrm{Pi}$, the results are significant in six cases and have the expected sign in two of the three remaining instances.

\section{An Alternative Model}

The analysis above has two limitations which can quickly be attended to. First, the migration model was one of net migration rather than gross migration. Given the large volume of high quality data on interstate gross migration flows, it might be appropriate and indeed desirable to use such data to examine our expectations hypothesis. Accordingly, this paper will now examine the effects of expected income changes on gross in-migration to states for the periods 19551960 and 1965-1970. Census data ([24] and [25]) will be used. Second, the paper has thus far assumed that the income increase expected in an area over a time period of given length is dependent solely upon $\Delta \mathrm{Yi}$, the rate of income increase in only the directly preceeding period of equal length. Obviously, expected income growth for a given time period might depend not only upon the rate of income growth in the preceeding period, but also may depend upon income growth rates in earlier periods. More specifically, the income increase expected in an area $\underline{i}$ over, say, the (five year period) 1955-1960 period would perhaps depend not only upon the income growth rate for (the five year period) 1950-1955, given by

$$
\frac{\mathrm{Y}_{1955-\mathrm{Y}^{\mathrm{Y}} 1950}}{{ }^{\mathrm{Y}} 1955}=\Delta_{1} \mathrm{Yi}
$$

but might depend also upon the growth rate in the (five year) period just preceeding, i.e., the rate given by

$$
\frac{\mathrm{Y}_{1950-\mathrm{Y}^{\mathrm{Y}} 1945}}{\mathrm{Y}_{1950}}=\Delta_{2} \mathrm{Yi}
$$

By the same token, the expected income growth in area $i$ for 1965-1970 would depend upon

$$
\begin{aligned}
& \frac{{ }^{\mathrm{Y}_{1965-}{ }^{\mathrm{Y}} 1960}}{{ }^{\mathrm{Y}} 1965}=\Delta_{1} \mathrm{Yi} \text { and } \\
& \frac{\mathrm{Y}_{1960-{ }^{\mathrm{Y}} 1955}}{{ }^{\mathrm{Y}_{1960}}}=\Delta_{2} \mathrm{Yi}
\end{aligned}
$$

The impact of $\Delta_{1} \mathrm{Yi}$ may well be greater than that of $\Delta_{2} \mathrm{Yi}$ since it may be viewed as a more current and hence more relevant and dependable indicator of changes for the near future. In any event, the model here argues that ex- 
pected income changes for a given period are formed on the basis of some form of weighted average of the appropriate values of $\underline{\Delta_{1}} \mathrm{Yi}$ and $\underline{\Delta_{2}} \mathrm{Yi}$.

To examine the migration impact of our two expectations factors, $\Delta_{1} \mathrm{Yi}$ and $\underline{\Delta_{2}}$ Yi, we examine the following migration model for $1955-1960$ and $1965-1970$ :

$$
\mathrm{Mgi}=\operatorname{Mgi}\left(\mathrm{Yi}, \Delta_{1} \mathrm{Yi}, \Delta_{2} \mathrm{Yi}, \mathrm{Ci}, \mathrm{Pi}\right)
$$

where $\mathrm{Mgi}=$ the gross migration rate to state $\underline{\mathrm{i}}$.

The actual form of (15) to be estimated is

(16) $\mathrm{Mgi}=\mathrm{a}+\mathrm{bYi}+\mathrm{c} \Delta_{1} \mathrm{Yi}+\mathrm{d} \Delta_{2} \mathrm{Yi}+\mathrm{eCi}+\mathrm{fPi}+\mathrm{u}$,

where $\underline{a}$ is a constant and $\underline{u}$ is an error term.

The results of estimating (16) for the periods 1955-1960 and 1965-1970 are given in Table II. The results, once again, are very gratifying: all of the variables had the hypothesized signs, and statistically significant (at the five percent level) coefficients were obtained in eight of the ten cases. Of particular interest is the fact that the term $\Delta_{1} \mathrm{Yi}$ did very well in both regressions while $\Delta_{2} \mathrm{Yi}$ did quite

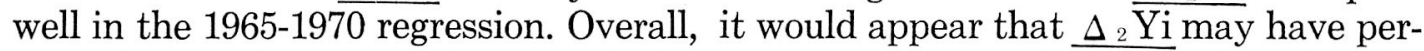
formed somewhat better than $\Delta_{2}$ Yi. In any event, it may be concluded that income expectations, as measured by our proxies $\underline{\Delta_{1} \mathrm{Yi}}$ and $\underline{\Delta_{2}} \mathrm{Yi}$, seem to influence migration decisions in an important way.

\section{Conclusion}

Our model of labor migration maintains that the migration decision is basically an investment decision in which migration from one area to another occurs if the discounted present value of the expected future stream of net benefits ${ }^{8}$ from such migration is positive. Within this framework, this paper has sought to ascertain the impact of income expectations on the interregional migration of labor. Our empirical findings indicate that income expectations, as measured in one set of cases by our proxy $\Delta \mathrm{Yi}$, and in another set by $\Delta_{1} \mathrm{Yi}$ and $\Delta_{2} \mathrm{Yi}$, for the most part have had a significant influence upon interstate migration in the United States. These findings are compatible with the results of other recent studies, including Bowles [4], Cebula and Vedder [5], Gallaway and Vedder [11], and Pack [20].

One possible implication of our analysis is that there may exist some form of "permanent income" or "life-cycle" hypothesis of migration. Just as consumption of commodities may be partially explicable in terms of a permanent income or life-cycle hypothesis, so may consumption of (investment in) "migration" be explained. This notion would seem especially appealing if migration in fact can be treated as a commodity. 
TABLE II

Gross Migration Results, 1955-1960 and 1965-1970+

\begin{tabular}{|c|c|c|c|c|c|c|c|}
\hline Period & $\mathrm{Yi}$ & $\Delta_{1} \mathrm{Yi}$ & $\Delta_{2} \mathrm{Yi}$ & $\mathrm{Ci}$ & $\mathrm{Pi}$ & $\mathbf{R}^{2}$ & F Ratio \\
\hline $1955-1960$ & $\begin{array}{c}0.13572 * \\
(0.09114)\end{array}$ & $\begin{array}{c}0.51308 * * \\
(0.17533)\end{array}$ & $\begin{array}{c}0.22458 * \\
(0.19366)\end{array}$ & $\begin{array}{c}-0.08345^{* *} \\
(.0 .03716)\end{array}$ & $\begin{array}{c}-0.01976 * * \\
(0.00415)\end{array}$ & .6723 & $18.104 * *$ \\
\hline $1965-1970$ & $\begin{array}{l}0.10437 * * \\
(0.04127)\end{array}$ & $\begin{array}{l}0.42919 * * \\
(0.15054)\end{array}$ & $\begin{array}{c}0.27418 * * \\
(0.16603)\end{array}$ & $\begin{array}{c}-0.19561 * * \\
(0.06518)\end{array}$ & $\begin{array}{c}-0.01814 * * \\
(0.00732)\end{array}$ & .6517 & $10.705 * *$ \\
\hline
\end{tabular}

+ Numbers in parentheses are standard errors of estimates.

* Significant at the ten percent level.

**Significant at the five percent level. 


\section{FOOTNOTES}

1. Some of the recent literature concerning these hypotheses includes Arak and Spiro [2], Bodkin [3], Houthakker [14], Laumas [15], Mayer [17], Modigliani and Ando [19], Peterson [21], and Wright [27].

2. Related to this, see, for example, Renas and Cebula [22].

3. For papers which briefly and generally deal with the topic of income expectations and migration, see Bowles [4], Cebula and Vedder [5], Pack [20], Sjaastad [23, 87-88], and Vanderkamp [26, 596].

4. Following the approach in Gatons and Cebula [12] and Sjaastad [23].

5. Before proceeding to the final section of the paper, a comment regarding the income data must be made. In particular, while the income data are generally regarded as quite reliable, we will make three small caveats. First, the early (especially 1880) income data is somewhat suspect, especially for Western states, largely due to fairly substantial interstate cost of living differentials. Second, state per capita income estimates are not available for 1890 or 1910 ; thus the $Y i$ and/or $\Delta Y i$ measures for the first four decades are imperfect. For example, net migration for the 1890's is regressed against growth in income for the 1880-1900 period rather than the current period (1890-1900) alone. Third, the estimates of interstate economic growth differentials for the 1920's may be somewhat inaccurate, owing to the switch from the Easterlin to the Department of Commerce per capita income estimates. In short, the results for the decades before 1930 should be interpreted somewhat more cautiously than those for the later decades.

6. The importance of $\mathrm{Yi}$ in explaining population movements in the United States is partly revealed when the elasticity of population with respect to income is calculated. Doing so at the mean level of per capita income, we obtained estimated elasticities in excess of .60 for the past two decades; a 0.6 percent decennial increase in population (not migration) is associated with each one percent differential in $Y i$, ceteris paribus. Since the total population increase in each of these decades was less than 20 percent, it appears that income differentials were important in interstate variations in population growth, although more study is needed on that point.

7. This is compatible with Greenwood [13] and Miller [18].

8. Which may be positive, negative or zero.

\section{REFERENCES}

- 1. Ando. A. and Modigliani, F., "The 'Life-Cycle' Hypothesis of Saving: Aggregate Implications and Tests," American Economic Review, March, 1963, 55-84.

2. Arak, M. and Spiro, A., "The Relationship Between Permanent Income and Measured Variables," Journal of Political Economy, May/June, 1971, 652-660.

3. Bodkin, R., "Windfall Income and Consumption," American Economic Review, September, 1959, $602-614$.

4. Bowles S., "Migration as Investment: Empirical Tests of the Human Investment Approach to Geographic Mobility," Review of Economics and Statistics, November, 1970, 356-362.

5. Cebula, R. J. and Vedder, R. K., "Migration, Economic Opportunity and the Quality of Life," Journal of Regional Science, Vol. 13, 1973, 205-211.

6. Commerce, U.S. Department of, Statistical Abstract of the United States: 1971.

7. Commerce, U.S. Department of, Survey of Current Business, August, 1953, 13.

8. Easterlin, Richard, "State Income Estimates," in Simon Kuznets and Dorothy S. Thomas, editors, Population Redistribution and Economic Growth: United States, 1870-1950, Vol. 1, 753.

9. Fabricant, R. A., "An Expectational Model of Migration," Journal of Regional Science, April, 1970, 13-24.

10. Friedman, M., A Theory of the Consumption Function. Princeton, 1957.

11. Gallaway, L. E. and Vedder, R. K., "An Economic Analysis of Labor Flows to the United States, 18981902," Ohio University Department of Economics Research Series No. 33.

12. Gatons, P. K. and Cebula, R. J., "Wage Rate Analysis: Differentials and Indeterminacy," Industrial and Labor Relations Review, January, 1972, 207-212.

13. Greenwood, M. J., "An Analysis of the Determinants of Geographic Labor Mobility in the United States," Review of Economics and Statistics, May 1969, 189-194.

14. Houthakker, H., "The Permanent Income Hypothesis," American Economic Review, June, 1958, 396-404.

15. Laumas, P., "A Test of the Permanent Income Hypothesis," Journal of Political Economy, September/ October, 1969, 857-861.

16. Lebergott, Stanley, "Migration in the United States, 1800-1960: Some New Estimates," Journal of Economic History, December, 1970, 846-847.

17. Mayer, T., "The Propensity to Consume Permanent Income," American Economic Review, December, 1966, 1158-1177.

18. Miller, E., “Is Out-Migration Affected by Economic Conditions?" Southern Economic Journal, January, 1973, 396-405. 
19. Modigliani, F. and Ando, A., 'The 'Permanent Income' and 'Life Cycle' Hypotheses of Saving Behavior: Comparison and 'Tests," in Consumption and Saving, edited by I. Friend and R. Jones, Vol. 2., Philadelphia, Pa.: University of Pennsylvania Press, 1960.

20. Pack J., "Determinants of Migration to Central Cities, 1955-1960," Journal of Regional Science, August, 1973, 249-260.

21. Peterson, R. E., "A Test of the Permanent Income Hypothesis of the Demand for Money Using Grouping as an Instrumental Variable," Journal of Political Economy, March/April, 1972, 403-408.

22. Renas, S. M. and Cebula, R. J., "Investment in Human Capital and the Appropriate Discount Rate," Social and Economic Studies, March, 1972, 61-71.

23. Sjaastad, L., "The Costs and Returns of Human Migration," Journal of Political Economy, October, 1962, Supplement, 80-93.

24. U. S. Bureau of the Census, Census of the Population: 1960, Migration Between State Economic Areas, 1962.

25. U. S. Bureau of the Census, Census of the Population: 1970, Migration Between State Economic Areas, 1972.

26. Vanderkamp, J., "Interregional Mobility in Canada: A Study of the Time Pattern of Migration," Canadian Journal of Economics, August, 1968, 595-608.

27. Wright, C., "Estimating Permanent Income: A Note," Journal of Political Economy, September/October, 1969, 845-850. 